\title{
On the Peculiarities of Consumption of the Population of the Arctic Regions of Russia
}

\author{
Skufina T.P. \\ Luzin Institute for Economic Studies - \\ Subdivision of the Federal Research Centre «Kola Science \\ Centre of the Russian Academy of Sciences», \\ Apatity, Russia, \\ skufina@iep.kolasc.net.ru
}

\author{
Baranov S.V. \\ Luzin Institute for Economic Studies - \\ Subdivision of the Federal Research Centre «Kola Science \\ Centre of the Russian Academy of Sciences», \\ Apatity, Russia
}

\begin{abstract}
The article is devoted to identifying the characteristics of consumption of the population in the Arctic regions of Russia, established on the basis of comparison with the general Russian situation. The need to separate the socio-economic space of the Russian Arctic from the all-Russian state is due to the presence of very specific characteristics (remoteness, cold discomfort, undeveloped social infrastructure, limited transport accessibility, less developed than the national average, the service sector, high average wages, etc.), which directly affect the consumption of various goods and services by the local population. The increased relevance of identifying the specifics of consumption of the population of the Russian Arctic is determined by the fact that in Russia regulatory documents are being formed that indicate an increase in the level of socio-economic development of this territory as the goal of the development of the Russian Arctic. saving. Based on the analysis of Sberbank's big data, it has been established that the average salary in the Arctic regions is significantly higher than the national average; revealed a noticeable excess of the average level of card use by the population of the Arctic, especially in the summer months and on New Year's holidays, as well as the specific behavior of the population of the Arctic in the credit sphere, which consists in the expectedly higher level of consumer and mortgage loans. The problem of population migration from the territory of the Russian Arctic is discussed, which indicates the insufficiency of higher incomes as a motivation for the consolidation and attraction of the population to the Russian Arctic.
\end{abstract}

Keywords-Russian Arctic, general Russian situation, population consumption, income, migration

\section{INTRODUCTION}

The quality and standard of living of people in different countries and regions of the world are at the center of discussions among politicians, managers and scientists. This is due to the generally accepted thesis that the quality and standard of living of the population are the basis for assessing social phenomena and processes, including for assessing socioeconomic development. The quality and standard of living of the population is considered as a result and at the same time as factors of the socio-economic development of a certain territory. It is generally accepted that one of the most important characteristics of the quality and standard of living of the population is the nature of its consumption [1]. Moreover, consumption patterns in a number of communities, including the Arctic, depend on the state of the environment, climate change, and a number of other non-economic factors [2]. The complexity of the problem of consumption predetermines the need for detailed scientific support of the life processes of the population in the Arctic.

Our study will analyze the specifics of consumption of the population of the Russian Arctic regions, identified on the basis of comparison with the general Russian situation. The need to separate the socioeconomic space of the Russian Arctic from the overall Russian situation is caused by the presence of very specific characteristics that directly affect the quality, standard of living, determining specifics of consumption of various kinds of goods and servicesby the population as well. Such specific characteristics of the Arctic include remoteness, cold discomfort, increased demand for vitamins and food, underdeveloped social infrastructure, limited transport accessibility, less developed service sector than the national average, high average wages [3-5]. The scientific significance of the study of the specifics of population consumption lies in establishing these specific characteristics of the socioeconomic space of the Russian Arctic in statistical data that reliably diagnose the characteristics of consumption of the population living in the Russian Arctic.

The increased relevance of identifying the specifics of consumption of the population of the Russian Arctic is also determined by the fact that at present in Russia a large set of regulatory documents is being formed, in which the Russian Arctic is designated as a special object of governmental management in order to increase the level of socioeconomic development of this territory [6-8]. A number of studies rightly note that the global trends in Arctic governance of other polar countries are consistent with this goal [4, 9-11]. However, there is also a growing number of negative trends in the development of the Russian Arctic, which emphasize the need to address the problems related to the standard and quality of life of the population, including its consumption $[5,6,12]$. We need to note that the state programs of all other polar countries (Canada, 
USA, Iceland, Finland, Norway, Sweden, Denmark) aimed at social support of the population of the Arctic are based on detailed scientific research on the specifics of population consumption $[1,2]$. Thus, the topic of research on the specifics of consumption of the population of the Russian Arctic regions is extremely important not only for the development of scientific ideas, but also for justifying effective management decisions that contribute to the goal of increasing the level of socioeconomic development of the Russian Arctic.

\section{RESEARCH MEthodS AND MATERIALS}

The specificity of our research is the use of big data collected by Sberbank of Russia. The expediency of this approach is dictated by a number of circumstances.

Firstly, the official statistics of the Federal State Statistics Service for the regions of Russia are provided with a delay. For example, at the time of writing, statistics reflecting the specifics of consumption were only available for the period up to 2018 .

Secondly, the methodological specifics of statistical accounting concerning the specifics of consumption by the population of the regions of Russia is constantly changing, which makes Rosstat data incomparable in the dynamic range of phenomena.

Thirdly, most of the data on the characteristics of population consumption provided by the Federal State Statistics Service of the Russian Federation was obtained from household surveys. The last survey in Russia was carried out in 2018. A new survey is scheduled for November-December 2020. The data of such a survey, like all the available scientists from similar household surveys, are characterized by a significant drawback: as a rule, the richest households do not participate in them. This bias should be taken into account when interpreting the data, but the magnitude of the error is unknown.

Big data collected by Sberbank of Russia is a valuable source of information about Russian society, consumer behavior in the regions of Russia, business development and the country's economy. Sberbank of Russia is one of the ten largest acquiring banks in the world, processing more than 14 billion transactions per year. This is the main bank for Russia. For the Arctic regions, where the level of development of the banking sector is much lower than the national average, it is Sberbank that processes almost all transactions. This allows for largescale and reliable research. The rationale for the feasibility and successful experience of using big data collected by Sberbank of Russia to analyze the specifics of consumer spending in the Arctic regions are presented in article [13]. In this paper, we will consider in more detail the specifics of consumer behavior of the Arctic population and the features of its dynamics.

The object of the study is the regions of Russia, which are fully located in the Arctic zone of the Russian Federation (the territory of the Arctic zone is enshrined in the Decree of the President of the Russian Federation of May 2, 2014. No. 296 "On the land territories of the Arctic zone of the Russian Federation" (with changes and additions dated June 27, 2017, May 13, 2019, March 5, 2020): Nenets Autonomous Okrug, Murmansk Region, Yamalo-Nenets Autonomous Okrug, Chukotka Autonomous Okrug.

The analysis includes the monthly data of Sberbank of Russia for the period 2013 (2015) - the beginning of 2019. The beginning of the period under review is limited by the availability of source data. We need to note that the initial data are adjusted by us to a form comparable with the beginning of 2013, regardless of whether the dynamic series began in 2013 or 2015. This allows using dynamic data series for comparison with each other, for example, to calculate correlation-regression dependencies.

\section{RESULTS AND DISCUSSION}

The key point is to consider the average wages in the regions of the Russian Arctic in comparison with the general situation in Russia (Fig. 1). It is obvious that it is the level of wages that determines the consumption possibilities of the population. It should be noted that the high wages established during the Soviet era were the main incentive for attracting people to the northern territories. For budgetary institutions located in the North of Russia, rates of wage increases are still in effect. The value of these coefficients is different (even within the same northern region) and depends on the level of discomfort of living. For the Arctic regions, the size of the coefficients determines double, and for a number of territories, almost triple the wages of state employees. However, again, if in Soviet times these increasing rates were valid for all employees, now they only apply to public sector employees. At the same time, in the Russian Arctic, there is a high level of wages in the extrabudgetary sphere, especially in the field of extraction and processing of natural resources. This confirms the consideration of the comparative dynamics of the average wage, which indicates the persistence of a significantly higher average wage in the regions of the Russian Arctic in comparison with the general situation in Russia (Fig. 1). Thus, the discrepancy between the average Russian and the average Arctic value is 1.7-2.3 times, depending on the year of the analyzed period. In the Arctic, there is a large amplitude of changes. For example, bonuses, which are traditionally available in December, in the Arctic regions are more than twice the average Russian payments. It is also characteristic that in the crisis year of 2015, the level of wages increased significantly until July 2015, then there was a decrease (but the wages remained above January 2015), then it jumped to 83.000 at the end of 2015, followed by the traditional decline in wages, which typical for each January in the whole country. The same dynamics by months is typical for subsequent years, with slight deviations. Numerous studies confirm that the economy of the Arctic regions is less prone to crises due to the extractive nature of the economy and its simplicity [14].

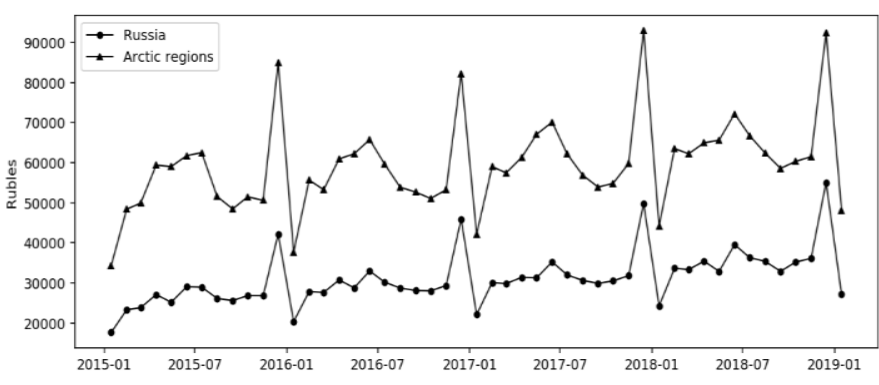

Fig. 1. Average wages in the Arctic regions and in Russia as a whole (monthly dynamics in 2013 prices)

Separately, it is worth noting the general trend characteristic of the population of Russia as a whole, as well as the population of the Arctic, a steady trend towards an increase in average 
spending on bank cards. In the absence of an upward trend in wages (since the data is presented in a comparable form) both in Russia as a whole and in the regions of the Russian Arctic (Fig. 1), this indicates an increase in payments in the digital bank.

The high level of average wages determines the possibility of higher expenditures by Arctic residents relative to the average Russian level. This is confirmed by the monthly dynamics of average spending using bank cards of Arctic residents, which are higher than in general in Russia (Fig. 2). Another reason for higher spending is the higher cost of goods and services in the Arctic regions.

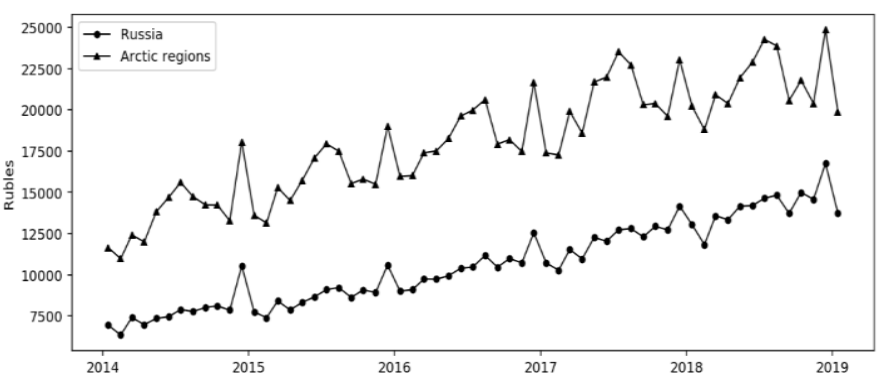

Fig. 2. Average card spendings of residents of the Arctic regions and of Russia as a whole (monthly dynamics in 2013 prices)

Careful consideration of the dynamics of average spending using cards allows to establish a feature of consumer behavior, high spending in the summer months. According to the average Russian data, the increase in bank card spending in the summer months is very small. This is due to the fact that a large part of the population of the Arctic goes on vacation, leaving the territory of permanent residence. A trip on vacation for Arctic residents, usually to favorable climatic conditions, which northerners await for the entire year, of course, entails significant budget expenses for travel, booking, restaurants, services, and purchase of consumer goods.

Increased spending by Arctic residents in the summer months is confirmed by the monthly dynamics of average spending in fast food restaurants, which tends to increase during May-August (Fig. 3). We need to note that such features are not observed in the global Russian data. It is noteworthy that the average check in a fast food restaurant for the inhabitants of the Arctic is much higher than the average Russian (Fig. 4). The cost of one check for Arctic residents in the summer months and in the New Year period is particularly high, with the amplitude of growth, as a rule, more than twice the average Russian values for the same period.

Also significant expenditures in the summer are due to the fact that according to Russian law, northerners in Russia have longer vacations than the average in Russia (the duration of leave is determined by the degree of discomfort of living and working conditions, for arctic workers is about 2 months per year) (Fig. 2). As a rule, northerners try to take vacations in the summer months. Employers try to meet the needs of people, especially those with children, to take their children out for the summer into favorable climatic conditions for recovery. Some of these increased vacation costs are the result of more limited access to goods and services in the Russian Arctic. Part of the problem is leveled by internet trade and Internet services. However, it is probably impossible to completely eliminate this problem of the lack of equal access to goods and services of the Arctic population in the foreseeable future of development.

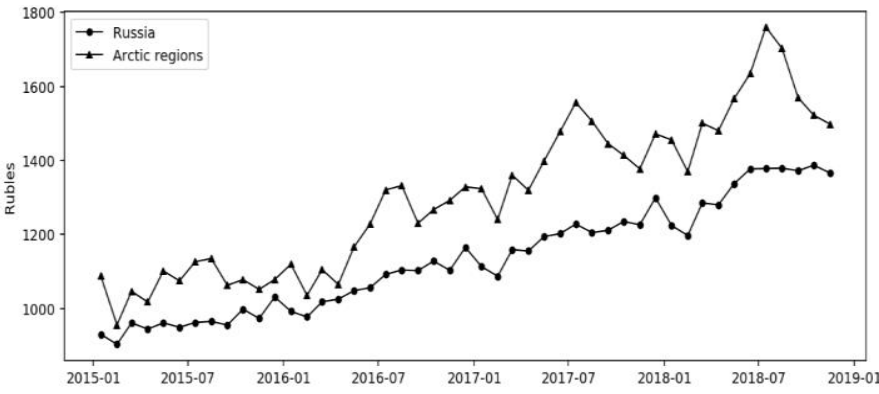

Fig. 3. Average spending in a fast food restaurant of the Arctic regions and Russia as a whole (monthly dynamics in 2013 prices)

Another feature of consumer behavior of Arctic residents is a more significant increase in spending during the New Year holidays (Fig. 2). The attraction of additional data on receipts for goods shows that this is due to the purchase of luxury goods, spending while traveling, purchase of expensive goods, including for the holiday table. We would like to mention that the New Year holidays account for the growth of monthly average spending in fast food restaurants (Fig. 3), and the sum of the average check (Fig. 4).

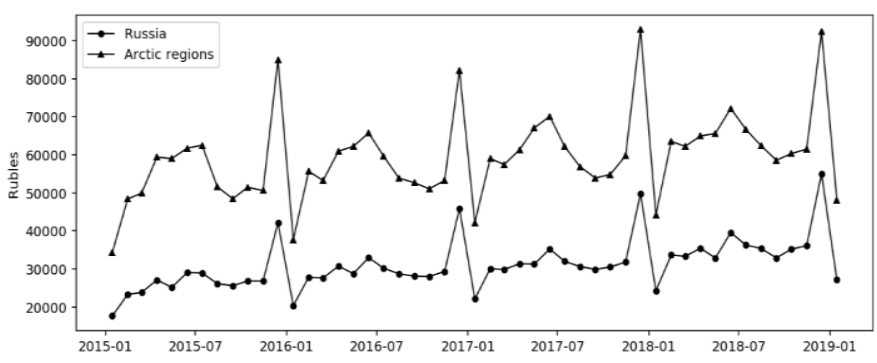

Fig. 4. Average check in fast food restaurants of residents of the Arctic regions and of Russia as a whole (monthly dynamics in prices in 2013)

The general trend of reducing the sum of the average check in the fast food restaurant for residents of the Arctic, and in General in Russia, is noteworthy. This indicates increased competition in the fast food restaurant segment in Russia, which leads to a decrease in the price of products (in prices related to the base year).

Further, we will consider the specifics of consumer behavior of Arctic residents in the credit sphere (Fig. 5, 6). The average amount of the application for consumer loans for a resident of the Arctic is 1.8 times higher than for the average Russian (Fig. 5). Taking into account that the average salary of a resident of the Arctic is 1.7-2.3 times (during the years of the analyzed period) (Fig. 1) the national rate, this shows the common trends in the consumer lending market. The similarity of the indicator's behavior for the Russian Arctic and Russia during the entire analyzed period is noteworthy. We need to note that since the end of 2015 there has been a general trend of increasing the average amount of consumer loan applications (Fig. 5) and the average amount of mortgage application for residents of the Arctic regions and Russia as a whole (Fig. 6). This indicates a slow but steady recovery in consumer demand after the 2014 crisis, which is known to have been interrupted by the development of the unpredictable COVID-19 crisis.

The average sumin applications for mortgage loans of residents of the Arctic is significantly higher than the average in Russia (Fig. 6). In addition to the obvious reason, the possibility of higher spending due to higher incomes of Arctic 
residents, it is also due to the increased migration outflow of people from the Arctic, respectively, the need to purchase housing in a more favorable climate. Our studies, based on the results of the population survey conducted in the Murmansk region in 2019 on a representative sample, allow us to expect an increase in the outflow of people from the territory of the Russian Arctic.

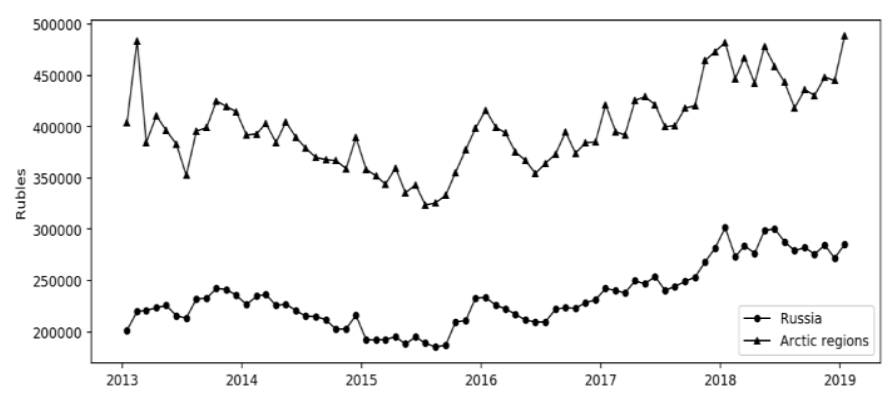

Fig. 5. Average amount of consumer loan applications of residents of the Arctic regions and of Russia as a whole (monthly dynamics in 2013 prices)

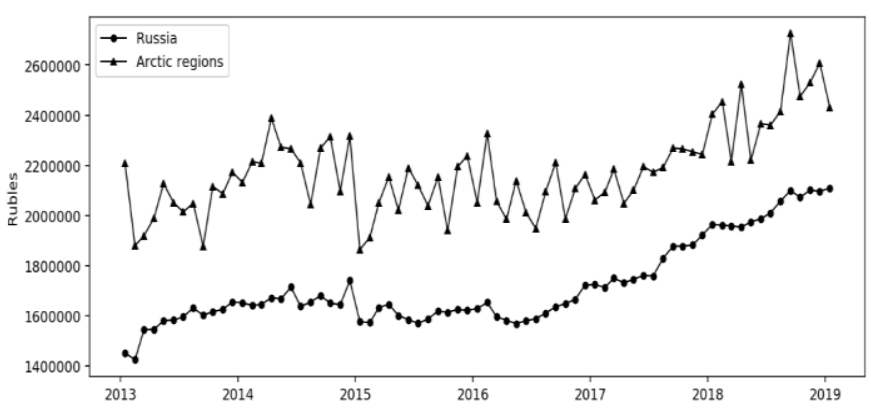

Fig. 6. Average mortgage applications of residents of the Arctic regions and of Russia as a whole (monthly dynamics in 2013 prices)

We need to note that migration outflow of the population from the territory of the Russian Arctic is considered one of the main problems of the socioeconomic development of this territory (Table I).

TABLE I. The Population of The Regions of the Russian ARCTIC, Thousands of PeOPLE

\begin{tabular}{|c|c|c|c|c|c|c|c|c|}
\hline Russian Arctic Region & 1960 & 1990 & 1995 & 2000 & 2005 & 2010 & 2015 & 2020 \\
\hline Nenets Autonomous Okrug & 37 & 52 & 44 & 41 & 42 & 42 & 43 & 44 \\
\hline Murmansk Region & 606 & 1191 & 1067 & 941 & 857 & 800 & 766 & 741 \\
\hline Yamalo-Nenets Autonomous Okrug & 64 & 489 & 478 & 496 & 515 & 524 & 540 & 544 \\
\hline Chukotka Autonomous Okrug & 47 & 162 & 96 & 62 & 51 & 49 & 51 & 50 \\
\hline
\end{tabular}

Consideration of population dynamics shows that during the Soviet Era, high incomes and prestige of employment in the Arctic attracted workers to the territory of the Russian Arctic, including highly skilled workers. Now the stimulating role of wages plays a smaller role, the promotion of prestige ofemployment in the Arctic does not work, so there is the opposite trend of population outflows.

\section{CONCLUSION}

The main conclusion that we can draw from the results of our study is that the consumption of the population of the Russian Arctic has a pronounced specificity. This specificity is due to a number of economic, social, natural and geographic factors. The economic factor is the high wages of Arctic residents, which are significantly higher than the average Russian, and at the same time, the less developed supply of goods and services in the Arctic. This, for example, increases consumer spending outside the residential area during extended vacations. The social factor is the desire to spend a longer "northern" vacation (compared to the vacation of workers in other regions of Russia) in favorable climatic conditions and the corresponding significant seasonal expenses in summer and during the New Year holidays, determined by desire. and the opportunity to spend time on vacation. Natural and geographic factors have a complex effect, for example, an increase in household spending due to higher prices for goods and services in the Arctic, as well as the pressure of a harsh climate causing population migration.

It should also be noted that in Soviet times, high incomes, active socio-economic development of the Arctic regions, active promotion of the prestige of employment in the Arctic led to a strong migration inflow. In the post-Soviet period, higher incomes are insufficient motivation for living in the harsh conditions of the Arctic, and the population is rapidly leaving this territory.

The presented results define promising directions for further research. First, it is necessary to take into account the differentiation of income and identify the specifics of consumption of different groups of the population. This is due to the fact that a number of studies demonstrate the growing problem of income stratification and the related problem of increasing poverty in the regions of the Russian Arctic. It should be noted that this feature is typical for a number of other polar countries $[1,2]$. Secondly, it is necessary to link the issues of quality of life, income level and specific consumption of the population of the Russian Arctic. These areas of further research are extremely important for substantiating decisions that affect the income of the population in the implementation of social and tax policies, as well as the quality of life in the formation of strategic programs for the socio-economic development of the Arctic regions of Russia.

\section{Acknowledgment}

The study includes materials obtained during realization of a state assignment Federal Research Center "Kola Science Center of the Russian Academy of Sciences" No. AAA-A18118051590118-0. 


\section{References}

[1] T.-A. Kenny, M. Fillion, J. MacLean, S.D. Wesche, and H.M. Chan, "Calories are cheap, nutrients are expensive - The challenge of healthy living in Arctic communities", Food Policy, 2018, vol. 80(C), pp. 39-54. DOI: https://doi.org/10.1016/j.foodpol.2018.08.006

[2] J. Todd, and C. Gregory,"Changes in Supplemental Nutrition Assistance Program real benefits and daily caloric intake among adults", Food Policy, 2018, vol. 79(C), pp. 111-120. DOI: https://doi.org/10.1016/j.foodpol.2018.06.004

[3] T.P. Skufina, and S.V. Baranov, "The phenomenon of unevenness of socio-economic development of cities and districts in Murmansk Oblast: specifics, trends, forecast, regulation", Economic and Social Changes: Facts, Trends, Forecast, 2017, vol. 10(5), pp. 66-82. (In Russ.). DOI: 10.15838/esc/2017.5.53.5

[4] S.V. Baranov, T.P. Skufina, and I.A. Gushchina, "The impact of the retirement age increase on the economy and attitudes of the population of the Murmansk oblast", Economic and Social Changes: Facts, Trends, Forecast, 2020, vol. 13(1), pp. 160-173. DOI: 10.15838/esc.2020.1.67.9

[5] L.V. Larchenko, and R.A. Kolesnikov, "Regions of the Russian arctic zone: State and problems at the beginning of the new development stage", International Journal of Engineering and Technology, 2018, vol. 7(3), pp. 369-375. DOI:10.14419/ijet.v7i3.14.17028

[6] V.N. Leksin, and B.N. Porfiryev, "Redevelopment of the Russian arctic region as a subject of system study and state program- and target-oriented management: issues of methodology", R-Economy, 2015, vol. 1(4), pp. 515-524. DOI: 10.15826/recon.2015.4.015

[7] The Economy of the Modern Arctic: Efficient Interaction and Integral Risks Management Underlying Success [Ekonomika sovremennoy Arktiki: $\mathrm{v}$ osnove uspeshnosti effektivnoe vzaimodeistvie i upravlenie integral'nymi riskami]: a collective monograph, Apatity: Kola SC RAS,
2020, 245 p. (In Russ.). DOI: 10.25702/KSC.978.5.91137.416.7

[8] M.L. Davydova, A.Y. Epifanov, O.I. Sharno, and M.N. Vanicheva, "Legal and institutional frameworks for the Arctic Zone of the Russian Federation", IOP Conference Series: Earth and Environmental Science, 2019, vol. 302, 012010. DOI: 10.1088/1755-1315/302/1/012010

[9] Yu.N. Gladkiy, V.D. Sukhorukov, and L.V. Larchenko, "Geophysical determinants of wind energy development in the Far North of Russia", IOP Conference Series: Earth and Environmental Science, 2020, vol. 459, 022071. DOI: $10.1088 / 1755-1315 / 459 / 2 / 022071$

[10] L. Suopajärvi, G.A. Poelzer, T. Ejdemo, E. Klyuchnikova, E. Korchak, and V. Nygaard, "Social sustainability in northern mining communities: A study of the European North and Northwest Russia", Resources Policy, 2016, vol. 47, pp. 61-68. DOI: 10.1016/j.resourpol.2015.11.004

[11] L. Heininen, K. Everett, B. Padrtova, and A. Reissell, Arctic Policies and Strategies - Analysis, Synthesis, and Trends, International Institute for Applied Systems Analysis, Laxenburg, Austria, 2019. DOI: 10.22022/AFI/11-2019.16175

[12] E. Korchak, and N. Serova, "High-quality reproduction of labor potential of Arctic territories: Migration factor", in The European Proceedings of Social \& Behavioural Sciences, 2019, vol. 77, pp. 1736-1742. DOI: 10.15405/epsbs.2019.12.04.235

[13] T.P. Skufina, S.V. Baranov, and M. Mitroshina, "On the consumer behavior of the Russian Arctic population", Asia Life Sciences, 2020, vol. 23(1), pp. 71-81.

[14] K. Pavlov, and V. Selin, "The industry of Russia's Northern Regions after anti-Russian sanctions", Social Sciences, 2018, vol. 49(3), pp. 57-68. DOI: $10.31857 / \mathrm{S} 013454860004$

[15] J. McCannon, Red Arctic: polar exploration and the myth of the north in the Soviet Union, 1932-1939, Oxford: Oxford University Press, 1998, $256 \mathrm{p}$. 